\title{
LITERASI INVENTARISASI HAMA DAN PENYAKIT TEMBAKAU DELI DI PERKEBUNAN SUMATERA UTARA
}

\author{
Ameilia Zuliyanti Siregar \\ Departemen Agroekoteknologi, Fakultas Pertanian Universitas Sumatera Utara \\ Corresponding author: ameilia@usu.ac.id; azsyanti@gmail.com
}

\begin{abstract}
Tobacco Deli" Sumatra, the belle of the European cigar tobacco is an economically valuable commodity exports as a source of foreign exchange. Deli tobacco leaf wrapper cigar known as the number one in the world, so it is still needed by plants producing high-quality cigars. Approach to literacy method in the inventory of the tobacco plant pest and disease appropriately in order to improve tobacco produktiviats to foreign countries. The main pests of tobacco plants were identified from the source of literacy is Thrips parvispinus, Spodoptera litura, Helicoperva armigera, Myzus persicae, Agrotis ipsilon, Heliothis, Meloydogyinae, Aphis sp, Thrips sp, Bemisia sp. While the types of diseases that often attack the tobacco plant was charred trunks, black shank, homeopathic leaf, spotting coelat, late blight and viruses. Preparation of seed healthy and productive; tillage seeding and planting land; Biological Control Agents consumption (BCA), rice husk ash, ash kitchen, liquid organic fertilizer and weed-free treatment that is an appropriate way to improve the productivity of tobacco as a commodity exporting country Indonesia.
\end{abstract}

Keywords: Literacy, inventory, pests and Ddiseases, tobacco, Deli.

\begin{abstract}
ABSTRAK
Tembakau Deli" Sumatera, sang primadona tembakau cerutu Eropa merupakan komoditas ekspor yang bernilai ekonomis sebagai sumber devisa negara. Daun tembakau Deli dikenal sebagai pembungkus cerutu nomor satu di dunia, sehingga tetap dibutuhkan oleh pabrik penghasil cerutu berkualitas tinggi. Pendekatan metode literasi dalam menginventarisasi hama dan penyakit tanaman tembakau secara tepat guna untuk meningkatkan produktiviats tembakau ke mancanegara. Hama-hama utama tanaman tembakau teridentifikasi dari sumber literasi adalah Thrips parvispinus, Spodoptera litura, Helicoperva armigera, Myzus persicae, Agrotis ipsilon, Heliothis, Meloydogyinae, Aphis sp, Thrips sp, Bemisia sp. Sedangkan jenis penyakit yang sering menyerang tanaman tembakau adalah hangus batang, lanas, patik daun, bercak coelat, busuk daun, dan virus. Persiapan benih yang sehat dan produktif; persiapan lahan pembibitan dan lahan tanam; pemakaian Agens Pengendali Hayati (APH), abu sekam, abu dapur, pupuk organik cair dan perawatan sehingga bebas gulma merupakan cara tepat dalam meningkatkan produktivitas tembakau sebagai komoditas ekspor negara Indonesia.
\end{abstract}

Kata kunci: Literasi, Inventarisasi, Hama dan Penyakit, Tembakau, Deli.

\section{PENDAHULUAN}

Tanaman tembakau dalam bahasa Indonesia merupakan serapan dari Bahasa Spanyol "tobacco" merupakan salah satu tanaman tropis asli Amerika. Asal mula tembakau tidak diketahui dengan pasti karena tanaman ini sangat tua dan telah dibudidayakan berabad - abad lamanya. Pada tahun 1556, tanaman tembakau 
diperkenalkan di Eropa, digunakan untuk keperluan dekorasi dan kedokteran/medis saja. Jean Nicot, yang pertama kali melakukan eksploitasi tanaman ini di Perancis. Kemudian, tanaman tembakau menyebar dengan sangat cepat di seluruh Eropa, Afrika, Asia, dan Australia (Matnawi, 1997).

Tembakau telah terkenal sebagai komoditi ekspor sejak dua setengah abad yang lalu, yakni ketika penguasa kolonial yang kemudian digantikan oleh pemodal swasta mengusahakan untuk pasaran Eropa. Kira - kira dua abad sejak diperkenalkannya tembakau oleh bangsa Portugis di Nusantara, tanaman tembakau merupakan tanaman untuk konsumsi kelompok elit, dan kemudian secara bertahap meluas menjadi konsumsi rakyat (Pedmo dan Djatmiko, 1991). Setelah itu tembakau menjadi popular di Eropa dan digunakan untuk beberapa keperluan, misalnya menghilangkan rasa lapar, mengurangi rasa kantuk atau pingsan, dan mengobati beberapa penyakit. Pertumbuhan tembakau sangat identik dengan perkembangan koloni - koloni pertama, terutama di daerah Virginia dan Maryland (Matnawi, 1997).

Tanaman tembakau merupakan tanaman komersial dengan memanfaatkan daunnya sebagai rokok, pipa atau tembakau kunyah. (chewing) atau untuk dihisap lewat hidung atau tembakau sedotan (snuff). Tembakau merupakan sumber nikotin yaitu, suatu zat aditif, dan juga sebagai bahan dasar untuk beberapa jenis insektisida. Di Indonesia, tembakau telah dikenal sejak 400 tahun yang lalu sebagai tanaman obat ataupun bahan halusinogen (Balitas, 1994).

Kultivar tembakau telah berkembang luas. Perkembangan tersebut telah melahirkan berbagai jenis tembakau baik berdasarkan tipologi, morfologi, adaptasi lokal ataupun berdasarkan cara pengolahan, penggunaan dan musim tanamnya. Sebagai contoh kultivar tembakau berdasarkan adaptasi lokasi yaitu: tembakau Virginia, Burley dan Turki. Tembakau merupakan komoditas penting yang menambah devisa bagi negara. Sumatera dahulu terkenal dengan "Tembakau Deli" nya yang sempat menguasai dunia. Tembakau Deli saat ini masih menjadi primadona tembakau cerutu, yang kegunaannya lebih diutamakan untuk pembungkus cerutu. Daun tembakau Deli dikenal sebagai pembungkus cerutu nomor satu di dunia, sehingga tetap dibutuhkan oleh pabrik penghasil cerutu berkualitas tinggi (Erwin, 2000).

Oleh karena itu dianggap penting dan perlu untuk mengembalikan nama terkenal tersebut menggunakan salah satu cara melalui literasi inventarisasi hama dan penyakit tanaman tembakau secara tepat guna untuk meningkatkan produktiviats tembakau ke mancanegara.

\section{BIOLOGI TEMBAKAU DELI}

Jenis tembakau berdasarkan pengolahannya antara lain, Pertama, Flue cured, tembakau yang pengolahannya dari daun hijau menjadi krosok dilakukan di dalam bangunan pengering dengan mengalirkan udara panas. Kedua, Sun cured, tembakau yang pengolahannya dengan sinar matahari dan lainnya. Sebagai contoh berdasarkan penggunaannya digolongkan tembakau cerutu, sigaret, kemyak, isap dan pipa. Berdasarkan musim tanamnya digolongkan dalam tembakau voor oogst dan na oogst. Dalam pengusahaan tembakau yang dominan di Indonesia dapat dikelompokkan dalam tembakau cerutu, rajangan dan virginia. Tembakau cerutu sampai saat ini umumnya diusahakan oleh PT Perkebunan Nusantara (BUMN).

Di negara Indonesia tembakau yang baik (komersial) hanya dihasilkan di daerah-daerah tertentu. Tanaman tembakau, curah hujan rata-rata 2000 $\mathrm{mm} /$ tahun, Suhu udara Yang cocok antara 
$21^{\circ}-32^{\circ} \mathrm{C}, \mathrm{pH}$ antara 5-6. Tanah gembur, remah, gampang mengikat air, memiliki tata air dan sirkulasi udara sehingga bisa meningkatkan drainase, ketinggian antara 200-3.000 m dpl. Kualitas tembakau sangat ditentukan oleh lokasi penanaman, hasil panen dan pengolahan pascapanen. Akibatnya, hanya beberapa tempat yang memiliki kesesuaian dengan kualitas tembakau terbaik, tergantung produk sasarannya.

Dalam sistematikanya tembakau tergolong dalam Divisio Plantae, Kelas Dicotyledonaea, Ordo Personatae, Famili Solanaceae, Sub Famili Nicotianae, Genus Nicotianae, Spesies Nicotiana tabacum L. Akar tanaman tembakau merupakan tanaman berakar tunggang yang tumbuh tegak ke pusat bumi. Akar tunggangnya dapat menembus tanah kedalaman 50- 75 $\mathrm{cm}$, sedangkan akar serabutnya menyebar ke samping. Selain itu, tanaman tembakau juga memiliki bulu-bulu akar. Perakaran akan berkembang baik jika tanahnya gembur, mudah menyerap air,dan subur.

$$
\text { Batang tanaman tembakau }
$$
memiliki bentuk batang agak bulat, agak lunak tetapi kuat, makin ke ujung, makin kecil. Ruas-ruas batang mengalami penebalan yang ditumbuhi daun, batang tanaman bercabang atau sedikit bercabang. Pada setiap ruas batang selain ditumbuhi daun, juga ditumbuhi tunas ketiak daun, diameter batang sekitar $5 \mathrm{~cm}$. Daun-daun tanaman tembakau berbentuk bulat lonjong (oval) atau bulat, tergantung pada varietasnya. Daun yang berbentuk bulat lonjong ujungnya meruncing, sedangkan yang berbentuk bulat, ujungnya tumpul. Daun memiliki tulang-tulang menyirip, bagian tepi daun agak bergelombang dan licin. Lapisan atas daun terdiri atas lapisan palisade parenchyma dan spongy parenchyma pada bagian bawah. Jumlah daun dalam satu tanaman sekitar 28 - 32 helai.

\section{HAMA DAN PENYAKIT TANAMAN TEMBAKAU}

Dalam budidaya tembakau sering mendapat kendala diserang hama dan penyakit dari jamur dan virus yang menyebabkan kualitas maupun kuantitas produksi menurun.Untuk menjaga hasil produksi maka perlu diketahui jenis-jenis penyakit, gejala dan pengendaliannya.

\section{Londrak (Thrips parvispinus)}

Hama Thrips atau Londrak (daerah) menyerang daun-daun dari bawah menuju ke atas, dengan cara menggaruk dan mengisap cairan daun. Gejala serangan ditandai dengan bagian bawah daun yang terserang berwarna keperakan, selanjutnya berubah menjadi kecoklatan. Daun tampak masak sebelum waktunya, kadang mengeriting dan melengkung ke atas. Jika dirajang warna tembakau kehitaman, tidak elastis seperti kertas dengan aroma pudar.

Hama ini mulanya dianggap hama sekunder sebagai vektor dari penyakit virus tembakau. Sejak seranganya meninggi di tahun 2004 dan selalu meningkat disetiap tahunnya maka hama ini tergolong hama penting pada tembakau. Hama ini menyebabkan kerugian hasil tembakau 50 $\%$, khususnya terhadap mutu tembakau menjadi rendah.

Thrips dewasa berwarna coklat dan hitam, cara jalan menyerong akan berkembang dengan cepat jika keadaan panas dan agak lembab. Pengendalian trips pada tanaman yang dilakukan dengan sistem pengendalian hama terpadu (PHT) adalah sebagai berikut:

a. Pemasangan perangkap lekat warna biru, putih atau kuning

b. Pemanfaatan musuh alami. Musuh alami potensial yang dapat digunakan untuk mengendalikan thrips adalah predator kumbang macan Menochilus sexmaculatus (1 ekor/tanaman) dan jamur patogen Verticillium lecanii (konsentrasi 3 x 108 spora/ml). Pelepasan kumbang predator $M$. sexmaculatus dan penyemprotan jamur patogen $V$. lecanii 
dilakukan mulai tanaman tembakau berumur satu minggu setelah tanam pada sore hari sekitar pukul 16.00. Di luar negeri, musuh alami trips sudah diperdagangkan seperti kepik Orius sp., tungau predator Amblyseius sp. dan jamur patogen $V$. lecanii.

3.Penyemprotan insektisida. Penyemprotan insektisida untuk mengendalikan trips pada tanaman merupakan upaya terakhir. Insektisida yang dianjurkan adalah insektisida yang selektif yaitu yang berbahan aktif Spinosad (Tracer 120 EC). Penggunaan insektisida dilakukan jika populasi hama tersebut telah mencapai ambang pengendalian. Menurut Moekasan et al (2005), nilai ambang pengendalian trips pada tanaman paprika adalah :

- Fase vegetatif $(0$ - 5 minggu setelah tanam) adalah 2,7 ekor trips/daun atas.

- Fase berbunga (6 - 11 minggu setelah tanam) adalah 0,3 ekor trips/daun pucuk dan 0,8 ekor trips/bunga.

- Fase berbuah (> 11 minggu setelah tanam) adalah 0,3 ekor trips/daun atas

\section{Ulat Grayak (Spodoptera litura F.)}

Ulat muda makan daun dengan menyisakan epidermis, sehingga daun menjadi transparan. Ulat tua memakan seluruh bagian daun dan yang ditinggalkan hanya tulang daunnya saja. Ulat mempunyai warna yang bervariasi, tetapi ada ciri utama, yaitu adanya garis menyerupai kalung berwarna hitam yang melingkar pada ruas ketiga. Kepompongnya berwarna coklat tua dan terdapat di permukaan tanah (Kalshoven 1981). Pengendalian ulat grayak dapat dilakukan dengan cara sebagai berikut:

a) Pengumpulan kelompok telur dan larva. Kelompok telur dan larva S. litura yang terdapat pada tanaman dikumpulkan lalu dimusnahkan.

b) Pemasangan feromonoid seks atau perangkap lampu untuk menekan populasi Tujuannya adalah untuk menangkap imago atau ngengat $S$. litura.

c) Pemanfaatan musuh alami. Musuh alami yang potensial mengendalikan ulat grayak adalah virus patogen SINPV (Spodoptera litura Nuclear Polyhedrosis Virus). Di pasaran musuh alami ini sudah dijual dengan nama Vir$X$ yang diproduksi oleh Perusahaan Dompet Duafa Republika. Penyemprotan virus patogen ini dilakukan mulai umur tanaman 1 minggu setelah tanam dengan interval 1 minggu

4) Penggunaan insektisida. Jika serangan ulat grayak sudah mencapai ambang pengendalian, yaitu 5\% kerusakan daun baru boleh digunakan insektisida. Insektisida yang dianjurkan adalah insektisida selektif seperti Spinosad (Tracer 120 EC).

\section{Ulat Pucuk Tembakau (Helicoverpa armigera)}

Helicoverpa armigera atau dikenal dengan sebutan ulat pupus, hama ini merusak daun pucuk, maupun pucuk tembakau bahkan pada kapsul (buah) ulat ini juga mau memakannya. di tahun 2015 tingkat serangannya cukup luas, serangan hama ulat pupus di Kabupaten Probolinggo menduduki peringkat ke dua setelah penyakit virus. Keadaan luas serangan hama ulat pupus dapat digambarkan dengan luas serangan tertinggi terjadi di Kecamatan Paiton, Krejengan, Besuk, Kotaanyar. Bulan serangan tertinggi di bulan Agustus 2015 (Trisnadi, 2015).

Menurut Kalshoven (1981), gejala yang ditimbulkan adalah daun muda dan pucuk berlubang bahkan ulat juga menggerek kapsul (buah), ada dua jenis Helicoverpa sp yang menyerang tembakau yaitu Halicoverpa armigera Hubner dan Helicoverpa assulta Genn. Ciri dari $H$. assulta meletakan telur diatas permukaan daun muda sedangkan $H$. armigera 
meletakan telur di bawah permukaan daun muda, dikarenakan ulat bersifat kanibal, jika mereka bertemu saudaranya saling memangsa, oleh karena itu secara naluri si induk betina jika meletakkan telurnya secara terpisah satu persatu pada tanaman. Betina mampu bertelur 200 -2000 butir. Kerugian yang diakibatkan oleh ulat pupus ini apabila sibetina meletakan telur secara tunggal dan telur itu menetas semua berapa tanaman yang rusak dan dapat menyebabkan kerugian yang tidak sedikit. Seranngan berat mengakibatkan kerugian sekitar $50 \%$. (Subiyakto, 2002).

Konsep pengendaian hama hendaknya dilakukan secara terpadu. Dalam hal ini yang penting adalah melakukan pengamatan perkembangan populasi hama. Jika populasi hama melewati titik kritis ambang ekonomi maka harus dilakukan pengendalian antara lain dengan cara:

a. Secara fisik, salah satunya melakukan sanitasi kebun yaitu membersihkan gulma disekitar tanaman tembakau. Hama ini bersifat polifaghus sehingga dimungkinkan gulma disekitar tanaman tembakau juga bisa digunakan untuk berkembang biak.

b. Secara mekanik, yaitu memungut ulat pada populasi tidak terlalu padat, kemudian memusnahkannya.

c. Secara biologis, dapat menggunakan agens hayati jamur Beauveria bassiana, Metarhizium, parasitoid Trichogramma nana, Nematoda entomopatogen Steinernema spp., dan Virus HaNPV.

d. Secara kultur teknis dapat dilakukan pergiliran tanaman dan waktu tanam serta system pengolahan tanah untuk memutus siklus hama.

e. Secara kimiawi, dilakukan sebagai alternative terakhir yaitu pada saat tingkat serangan tinggi $(>20 \%)$. Insektisida yang dapat digunakan antara lain Permetrin 2 gram/liter atau Betasiflutrin 25 gram/liter, Thiodan 4 $\mathrm{ml} /$ liter,dan Lannate $2 \mathrm{ml} /$ liter.

\section{Kutu Daun Persik (Myzus persicae)}

Kutu daun persik sering pula disebut sebagai kutu daun tembakau. Nimfa dan serangga dewasa menyerang daun-daun muda, dengan cara menusuk dan mengisap cairan daun. Gejala serangan ditandai dengan perubahan tekstur daun menjadi keriput, terpuntir, berwarna kekuningan, pertumbuhan tanaman kerdil, daun menjadi layu dan akhirnya mati. Di samping itu, kutu daun merupakan vektor penyakit virus PLRV dan PVY. Tubuhnya berwarna kuning kehijauan dengan panjang tubuh berkisar antara 0,8 - 1,2 mm. Pengendalian kutu daun persik pada tanaman tembakau yang dilakukan dengan sistem PHT berikut :

1. Pemanfaatan musuh alami. Di alam, kutu daun persik mempunyai musuh alami yang potensial yaitu parasitoid Aphidius sp., kumbang macan $M$. sexmaculatus, dan larva lalat Syrphidae. Pelepasan kumbang macan $M$. sexmaculatus dilakukan sejak tanaman tembakau berumur 1 minggu setelah tanam dan diulang setiap minggu.

2) Penggunaan insektisida. Jika populasi kutu daun persik telah mencapai ambang pengendalian, yaitu 7 ekor/10 daun, maka pertanaman disemprot dengan insektisida Fipronil (Regent 50 EC). Gejala: Kutu ini merusak tanaman tembakau dan menghisap cairan daun tanaman, menyerang di pembibitan dan pertanaman sehingga pertumbuhan tanaman terhambat. Kutu ini menghasilkan embun madu yang menyebabkan daun menjadi lengket dan ditumbuhi

cendawan berwarna hitam. Kutu daun secara fisik mempengaruhi warna, aroma dan tekstur dan selanjutnya akan mengurangi mutu dan harga, secara khemis kutu daun mengurangi kandungan alkaloid, gula, rasio gula alkaloid dan meningkatkan total nitrogen daun. Kutu daun dapat 
menyebabkan kerugian sampai 50\%, kutu daun dapat menyebabkan kerugian 22 - 28\% pada tembakau flue-cured. Pengendaliannya: Mengurangi pemupukan $\mathrm{N}$ dan melakukan penyemprotan insektisida imidaklorid apabila lebih besar dari 10\% tanaman dijumpai koloni kutu tembakau (setiap koloni sekitar 50 ekor kutu).

\section{Ulat Tanah (Agrotis ipsilon)}

Gejala yang timbul: dengan daun terserang berlubang-lubang terutama daun muda sehingga ada tangkai daun rebah. Pengendalian: Pangkas daun sarang telur/ulat, penggenangan sesaat dan semprot Pestona.

\section{Penggerek Pucuk (Heliothis sp)}

Gejala yang timbul: dengan daun pucuk tanaman terserang berlubang-lubang dan bila dibiarkan akan habis. Pengendalian: mengumpulkan dan musnah telur / ulat, sanitasi kebun dan semprot Pestona

\section{Nematoda (Meloydogyne sp)}

Gejala yang timbul: Bagian akar tanaman tampak bisul-bisul bulat, tanaman bisa kerdil, layu, daunberguguran dan akhirnya akan mati.

Pengendalian: Sanitasi kebun, pemberian GLIO diawal tanam, PESTONA

\section{Kutu-Kutuan (Aphis sp, Thrips sp, Bemisia sp)}

disebabkan virus. Pengendalian: Mengunakan predator Koksinelid, Natural BVR, Gangsir (Gryllus mitratus), jangkrik (Brachytry pesportentosus), orong-orong (Gryllotalpa africana), semut geni (Solenopsis geminata), belalang banci (Engytarus tenuis).

Sedangkan yang tergolong kategori penyakit pada tanaman tembakau berikut ini:

\section{Hangus Batang (Damping off)}

Disebabkan karena jamur Rhizoctonia solani. Gejala yang timbul: Batang tanaman yang terinfeksi akan mengering dan berwarna coklat sampai hitamseperti terbakar. Pengendalian : mencabut tanaman yang terserang dan bakar dan pencegahan awal dengan Natural GLIO.

\section{Lanas}

Disebabkan karena ulah Phytophora parasitica var. nicotinae. Gejala yang timbul: munculnya bercakbercak pada daun berwarna kelabu yang akan meluas, pada batang,terserang akan lemas dan menggantung lalu layu dan akhirnya mati. Pengendalian: Mencabut tanaman yang terserang dan bakar, semprotkan Natural GLIO.

\section{Patik Daun}

Dikarenakan ulah jamur Cercospora nicotianae. Gejala: di atas daun terdapat bercak bulat putih hingga coklat, bagian daunyang terserang menjadi rapuh dan mudah robek. Pengendalian: menggunakan desinfeksi bibit, renggangkan jarak tanam, olah tanah intensif, gunakan airbersih, bongkar dan bakar tanaman terserang, semprot Natural GLIO.

\section{Bercak Coklat}

Penyebab oleh jamur Alternaria longipes. Gejala yang timbul: Ada bercak-bercak coklat, selain tanaman dewasa penyakit ini juga menyerangtanaman di persemaian. dan perlu anda tahu jamur juga menyerang batang dan biji. Pengendalian: dengan mencabut dan membakar tanaman yang terserang.

\section{Busuk Daun}

Penyebab: Bakteri Sclerotium rolfsii. Gejala yang timbul: Mirip dengan lanas namun daun membusuk, akarnya bila diteliti diselubungi olehmassa cendawan. 
Pengendalian: mencabut dan bakar tanaman terserang, semprot Natural GLIO.

\section{Virus}

Penyebab: virus mozaik (Tobacco Virus Mozaic/TVM), Kerupuk (Krul), Pseudomozaik, Marmer, Mozaik ketimu (Cucumber Mozaic Virus). Gejala yang sering terjadi: Pertumbuhan tanaman menjadi lambat. Pengendalian: dengan menjaga sanitasi kebun, tanaman yang terinfeksi di cabut dan dibakar.

\section{Faktor-Faktor Yang Mempengaruhi Pertumbuhan Tembakau}

Hal-hal yang sangat perlu diperhatikan pada saat penanaman dan perawatan tembakau adalah sebagai berikut :

1. Persiapan benih yang sehat dan produktif.

2. Persiapan lahan pembibitan dan lahan tanam (diupayakan lahan jangan ditanah bekas tanaman sumber infeksi hama dan penyakit atau tumpang sari dengan tanaman sumber infeksi hama dan penyakit).

3. Manfaatkan pemakaian Agens Pengendali Hayati (APH) dan Pupuk organik cair sebagai imunisasi tanaman, penyehat dan penyubur tanaman.

4. Manfaatkan abu sekam atau abu dapur/tomang saat penanam persemaian atau penanam dilahan sebagai penghambat penyebaran penyakit karena virus atau bakteri.

5. Kabersihan lahan terhadap tanaman pengganggu (gulma) yang merupakan tempat persembunyian hama atau inang penyakit dan pesaing hara yang yang dibutuhkan tanaman pokok.

\section{SIMPULAN}

Hama-hama utama tanaman tembakau adalah Thrips parvispinus, Spodoptera litura, Helicoperva armigera, Myzus persicae, Agrotis ipsilon, Heliothis, Meloydogyinae, Aphis sp, Thrips sp,
Bemisia sp. Sedangkan jenis penyakit yang sering menyerang tanaman tembakau adalah hangus batang, lanas, patik daun, bercak coelat, busuk daun, dan virus. Persiapan benih yang sehat dan produktif; persiapan lahan pembibitan dan lahan tanam; pemakaian Agens Pengendali Hayati (APH), abu sekam, abu dapur/tomang, pupuk organik cair dan perawatan sehingga bebas gulma merupakan cara tepat dalam meningkatkan produktivitas tembakau sebagai komoditas ekspor negara Indonesia.

\section{Saran}

Hindari pembibitan yang berada di pinggir jalan umum, didekat perumahan perkampungan karena ada beberapa jenis gulma di sekitar perumahan yang menjadi sarang hama dan penyakit tanaman tembakau.

\section{Ucapan Terima Kasih}

Penghargaan yang setinggitingginya disampaikan kepada Fakultas Pertanian Universitas Sumatera Utara yang melaksanakan kegiatan Seminar Nasional untuk perkebunan Tembakau Deli dalam Rangka Dies Natalis ke-60 Fakultas Pertanian USU. Terima kasih kepada Sdr.Indra Matondang yang membantu berbagi informasi tentang tanaman tembakau, semoga kita tetap dapat bersinergi ke depan.

\section{DAFTAR PUSTAKA}

Anonim, 2010. Pengendalian Hama dan Penyakit dalam Budidaya Tembakau. http://tembakaurajangan.blogspot.co. id/2011/12/ Diakses tgl.28 Juli 2016.

Anonim. 2012. Hama dan Penyakit pada Tanaman Terung. http://diarymonic.blogspot.com/2012 /04/ diakses tanggal 18 Juli 2016.

Anonim, 2014. Hama dan Penyakit Tanaman Tembakau. www.petanihebat.com/2013/10/hama - dan-penyakit-tanaman- 
tmbakau.html. Diakses pada tanggal 14 Oktober 2016.

Balittas (Balai Penelitian Tanaman Tembakau dan Serat), 1994. Situasi Pertembakauan di Indonesia. Laporan bulan Januari 1994. Balai Penelitian Tanaman Tembakau dan Serat, Malang.

Erwin, 2000. Hama dan Penyakit tembakau Deli. Balai Penelitian Tembakau Deli PTPN II (Persero), Medan. Hlm 1-2.

Kalshoven. L.G.E.1981. Pests of Crops in Indonesia. Bev by Vander Lean. PT. Ichtiar Baru Van Hoeve. Jakarta. $701 \mathrm{p}$.

Matnawi, H., 1997. Budidaya Tembakau di bawah Naungan. Kanisius. Yogyakarta.

Pedmo, S., dan E. Djatmiko, 1991. Tembakau Kajian Sosial Ekonomi. Aditya, Media,Yogyakarta.

Satrio S. 2000. Hama Penting Tanaman Tembakau.

http://tembakaurajangan.blogspot.co. id /2011/12/>. Diakses tanggal, 30 Juli 2016.

Semangun. Haryono. 2007. PenyakitPenyakit Tanaman Holtikultura di Indonesia (Edisi Kedua). Gadjah Mada University Press, Yogyakarta.

Subiyakto, 2002. Hama hama penting tanaman tembakau cerutu dan Pengendaliannya, Balittas Malang

Trisnadi R K. 2015. Serangan Hama dan Penyakit Tembakau Tahun 2015 di Kabupaten Probolinggo dan Dampak Kerugian. Dinas Perkebunan dan Kehutanan. Probolinggo.

Trisnadi R K., 2016. Hama Penting Tanaman Tembakau. POPT. Jakarta

W. A. Nasution. 2011. Latar Belakang Tembakau.

Repository.usu.ac.id/bitsream/.../5/c apter\%201. pdf. Diakses pada tanggal 16 Oktober 2015. 
Lampiran 1.Gambar Hama dan Penyakit Yang Menyerang Tanaman Tembakau
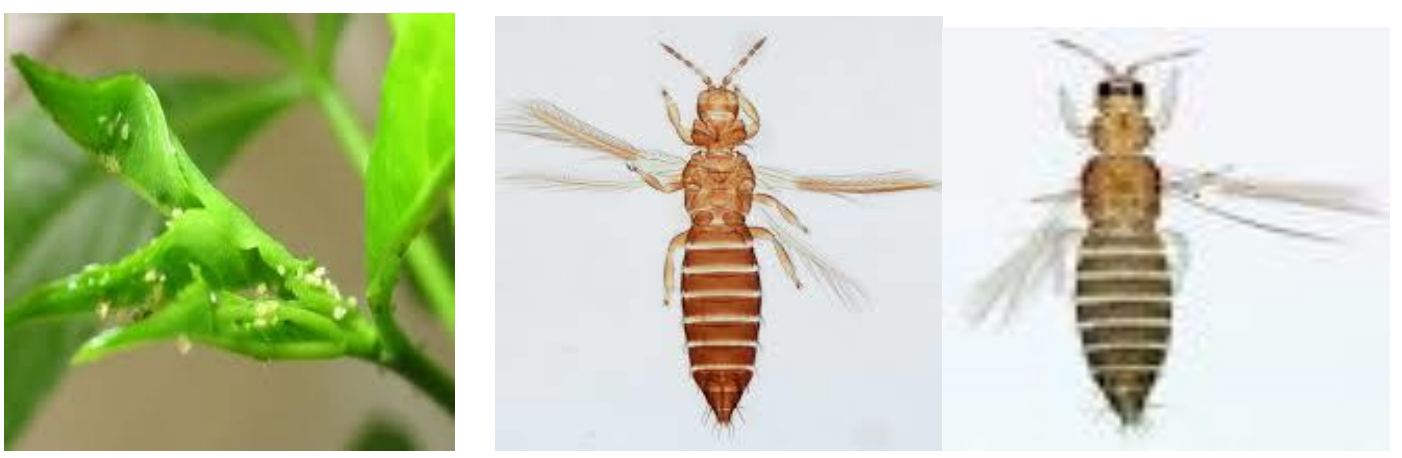

Thrips parvispinus


Helicoverpa armigera 



Myzus persicae 